\title{
PATEN UNTUK STUDI KASUS iTUNES PHONE
}

\author{
Mas Agus Eliyani \\ 155100047, 785567899 \\ Fakultas Komputer \\ masaguseliyani.student@umitra.ac.id
}

\begin{abstract}
iBooks adalah sebuah aplikasi buku elektronik Apple Inc. untuk sistem operasi iOS dan perangkat-perangkatnya. Peluncurannya berbarengan dengan iPad pada tanggal 27 Januari 2010[1] dan dirilis untuk iPhone dan iPod Touch pada pertengahan 2010 sebagia bagian dari pemutakhiran iOS 4.[2] iBooks bukan aplikasi bawaan perangkat iOS. Pengguna dapat mengunduh iBooks secara gratis dari iTunes App Store.
\end{abstract}

iBooks mendapatkan konten ePub dari iBookstore. Pengguna juga dapat menambahkan berkas ePub dan PDF-nya sendiri melalui sinkronisasi data dengan iTunes. Selain itu, berkas-berkas tersebut dapat diunduh ke iBooks melalui Safari atau Apple Mail. Aplikasi ini juga mampu menampilkan buku elektronik yang memiliki fitur multimedia.[1][3] Menurut informasi produk per Maret 2010, iBooks akan mampu "membacakan konten halaman apapun [kepada pengguna]" dengan VoiceOver.[4][5]

Pada 19 Januari 2012, di sebuah acara pendidikan di New York City, Apple mengumumkan peluncuran iBooks 2 secara gratis yang dapat beroperasi di mode lanskap dan memiliki fitur baca interaktif. Selain itu, aplikasi baru iBooks Author diluncurkan di Mac App Store. iBooks Author memungkinkan semua orang membuat buku teks interaktif untuk dibaca di iBooks dan iBookstore diperluas dengan ditambahkannya kategori buku teks.

Kata Kunci : Pengetahuan dan Perubahan. 


\section{A. INTRODUCTION}

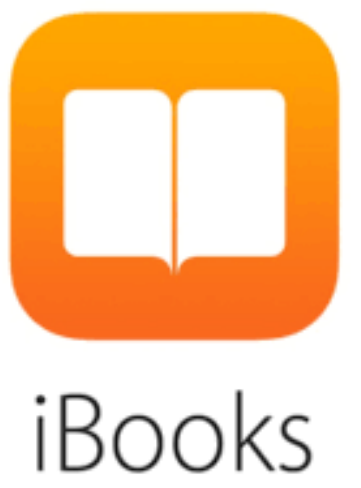

iBooks adalah sebuah aplikasi e-book authoring oleh Apple Inc Dokumen dibuat dengan iBooks Author yang dapat diekspor sebagai file PDF atau di publikasikan ke Apple iBooks Bookstore. iBooks Author adalah alat untuk "pendidik dan penerbit yang lebih kecil untuk membuat buku anda sendiri". Dokumen yang di buat melalui aplikasi ini mungkin hanya dijual untuk biaya jika anda diterima dan didistribusikan oleh Apple, tetapi penulis juga memiliki polian untuk mendistribusikan karya mereka dimana saja jika pekerjaan tersebut didistribusikan secara gratis. Banyak aspek dokumen dapat diedit di WYSIWYG fashion, termasuk teks, font, warna, latar depan dan gambar latar belakang, widget interaktif, dan grafik. Tabel isi dan Glosari dapat dikelola dengan beberapa otomatisasi. User interface dan fitur editing telah digambarkan sebagai hampir identik dengan
Keynote dan Pages produk Apple.

Fitur yang terdapat dalam aplikasi ini adalah :

Designed templates dari apple Berikan buku Anda awal yang besar dengan template yang mencakup pilihan desain halaman dengan pencocokan font, warna, dan tekstur.

Cepat menyesuaikan buku Anda dengan teks dan gambar membuat layout baru, dan bahkan menyimpan template kustom.

Mudah menambahkan penutup video pengenalan, daftar isi, halaman hak cipta, dedikasi, dan kata pengantar.

Teks dan layout yang indah

Gunakan berbagai gaya teks termasuk font kustom untuk memberikan buku Anda terlihat kaya konsisten.

Tambah teks, bentuk, grafik, tabel, dan media dimanapun pada halaman.

Impor bab yang ditulis dalam Pages atau Microsoft Word dan menerapkan tata letak yang besar tampak dari template Anda saat ini.

Tambahkan ekspresi matematika canggih dengan mengedit persamaan asli baru menggunakan kedua LaTeX dan notasi MathML.

Tambahkan kata apapun untuk glossary dengan satu klik yang mudah termasuk foto, gambar, 
grafik, tabel, dan bentuk samping definisi apapun.

Secara otomatis membuat tampilan potret buku lansekap Anda, yang memungkinkan pembaca untuk fokus pada teks.

Widgets Multi-Touch

Pilih dari berbagai widget yang menambah Multi-Touch interaktivitas ke buku Anda.

Tambah galeri foto, ulasan bab, film, file audio, presentasi Keynote, bergulir sidebar, popover, gambar interaktif yang dinamis dengan callouts, objek 3D, atau HTML kustom di mana saja di buku Anda.

Banyak widget termasuk pengganti untuk judul, keterangan dan nomor secara otomatis sehingga Anda dapat referensi mereka dalam teks utama Anda.

Tambahkan deskripsi akses ke widget apapun sehingga dapat digunakan oleh pembaca melihat-gangguan mudah dengan VoiceOver

Ekspor untuk iBookstore atau iTunes U

Pratinjau buku di iBooks pada iPad untuk melihat tampilannya dan pekerjaan.

Kirim buku Anda ke iBookstore untuk dijual atau download gratis di beberapa langkah sederhana.

Ekspor buku Anda dalam format iBooks untuk berbagi di iTunes $\mathrm{U}$ atau memberikan kepada orang lain.

Ekspor buku Anda sebagai file PDF.
B. CONTENT

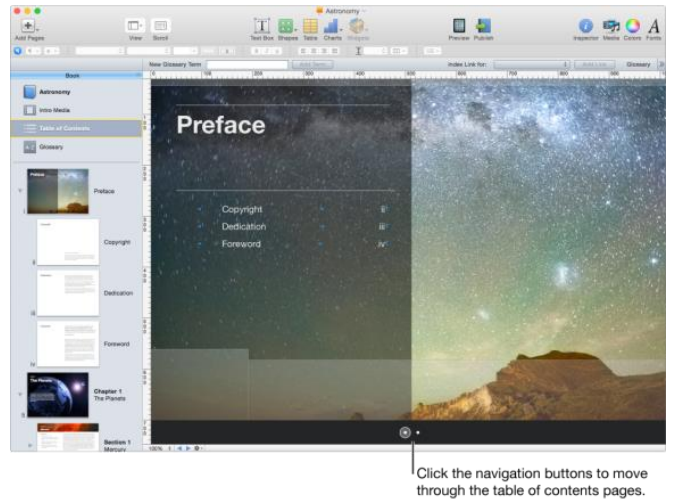

Setiap buku memiliki daftar isi yang diperbarui secara otomatis. Anda dapat melihat daftar isi kapan saja dengan memilih Daftar Isi di sidebar. Daftar isi dapat meliputi:

Judul bab dan bagian: Semua judul bab dan bagian termasuk dalam daftar isi secara default. Jika Anda menghapus bagian dari daftar isi, semua bagian lain yang menggunakan tata letak yang sama juga dihapus.

Teks yang menggunakan gaya paragraf tertentu: Secara default, daftar isi menyertakan semua paragraf di buku yang menggunakan gaya Heading 1 dan Heading 2, tetapi Anda bisa menyertakan gaya mana pun yang Anda suka. Gaya paragraf muncul dalam daftar isi hanya di templat lanskap dalam tampilan gulir. (Untuk informasi lebih lanjut tentang menerapkan gaya paragraf, lihat Memformat teks menggunakan gaya.) 
Cara daftar isi terlihat oleh pembaca tergantung pada templat yang Anda gunakan:

Dalam templat lansekap yang tidak dalam tampilan gulir (ditampilkan di bawah), setiap bab memiliki halaman kontennya sendiri, dengan tombol navigasi di bagian bawah.

Dalam templat ePub atau templat lanskap dalam tampilan gulir, seluruh daftar isi buku terlihat sebagai daftar yang dapat diperluas.

Dalam templat potret, setiap bab memiliki halaman kontennya sendiri, dengan tombol navigasi di bagian bawah.

Add or remove items in the table of contents

If the Document inspector isn't open, click the Inspector button in the toolbar, then click the Document inspector button .

Click the TOC button.

Do any of the following:

Add an item: Click the Add pop-up menu, choose Add Paragraph Style, and choose an option from the submenu.

Remove an item: Select the item you want to remove and click the Delete button .

Show or hide page numbers in the table of contents
If the Document inspector isn't open, click the Inspector button in the toolbar, then click the Document inspector button .

Click the TOC button.

Select or deselect "Show page numbers in TOC."

\section{CONCLUSION}

iBooks Author sebagai alat untuk "pendidik dan penerbit yang lebih kecil untuk membuat buku mereka sendiri". Dokumen yang dibuat oleh iBooks Author hanya dapat dijual dengan biaya jika diterima oleh dan didistribusikan oleh Apple, tetapi penulis juga memiliki opsi untuk mendistribusikan karya mereka di mana saja jika karya tersebut didistribusikan secara gratis.Banyak aspek dokumen yang dapat diedit dengan cara WYSIWYG, termasuk teks, font, warna, gambar latar depan dan latar belakang, widget interaktif, dan bagan. Daftar isi dan daftar istilah dapat dikelola dengan beberapa otomatisasi.

\section{DISCUSSION}

Tidak ada diskusi

\section{E. REFERENCE}

[1] O. M. Febriani and A. S. Putra, "Sistem Informasi Monitoring Inventori Barang Pada Balai Riset Standardisasi Industri Bandar Lampung," J. Inform., 
vol. 13, no. 1, pp. 90-98, 2014.

[2] A. S. Putra, "Paperplain: Execution Fundamental Create Application With Borland Delphi 7.0 University Of Mitra Indonesia," 2018.

[3] A. S. Putra, "2018 Artikel Struktur Data, Audit Dan Jaringan Komputer,” 2018.

[4] A. S. Putra, "ALIAS MANAGER USED IN DATABASE DESKTOP STUDI CASE DB DEMOS."

A. S. Putra, "COMPREHENSIVE SET OF PROFESSIONAL FOR DISTRIBUTE COMPUTING."

[6] A. S. Putra, "DATA ORIENTED RECOGNITION IN BORLAND DELPHI 7.0.”

[7] A. S. Putra, "EMBARCADERO DELPHI XE 2 IN GPUPOWERED FIREMONKEY APPLICATION."

[8] A. S. Putra, "HAK ATAS KEKAYAAN INTELEKTUAL DALAM DUNIA TEKNOLOGY BERBASIS REVOLUSI INDUSTRI 4.0."

[9] A. S. Putra, "IMPLEMENTASI PERATURAN PERUNDANGAN UU. NO 31 TAHUN 2000 TENTANG DESAIN INDUSTRI BERBASIS INFORMATION TECHNOLOGY."

[10] A. S. Putra, "IMPLEMENTATION OF PARADOX DBASE." A. S. Putra, "IMPLEMENTATION OF TRADE SECRET CASE STUDY SAMSUNG MOBILE PHONE."

[12] A.

S. Putra,
"IMPLEMENTATION

PATENT FOR APPLICATION WEB BASED CASE STUDI WWW. PUBLIKLAMPUNG. COM."

[13] A "IMPLEMENTATION SYSTEM FIRST TO INVENT IN DIGITALLY INDUSTRY."

[14] A. S. Putra, "MANUAL REPORT \& INTEGRATED DEVELOPMENT

ENVIRONMENT BORLAND DELPHI 7.0."

[15] A. S. Putra, "PATENT AS RELEVAN SUPPORT RESEARCH."

[16] A. S. Putra, "PATENT FOR RESEARCH STUDY CASE OF APPLE. Inc."

[17] A. S. Putra, "PATENT PROTECTION FOR APPLICATION INVENT."

[18] A. S. Putra, "QUICK REPORT IN PROPERTY PROGRAMMING."

[19] A. S. Putra, "REVIEW CIRCUIT LAYOUT COMPONENT

REQUIREMENT ON ASUS NOTEBOOK."

[20] A. S. Putra, "REVIEW TRADEMARK PATENT FOR INDUSTRIAL TECHNOLOGY BASED 4.0.”

[21] A. S. Putra, "TOOLBAR COMPONENT PALLETTE IN OBJECT ORIENTED PROGRAMMING."

[22] A. S. Putra, "WORKING DIRECTORY SET FOR PARADOX 7."

[23] A. S. Putra, "ZQUERY CONNECTION IMPLEMENTED 
PROGRAMMING STUDI

CASE PT. BANK BCA Tbk."

[24] A. S. Putra, D. R. Aryanti, and I. Hartati, "Metode SAW (Simple Additive Weighting) sebagai Sistem Pendukung Keputusan Guru Berprestasi (Studi Kasus: SMK Global Surya)," in Prosiding Seminar Nasional Darmajaya, 2018, vol. 1, no. 1, pp. 85-97.

[25] A. S. Putra and O. M. Febriani, "Knowledge Management Online Application in PDAM Lampung Province," in Prosiding International conference on Information Technology and Business (ICITB), 2018, pp. 181-187.

[26] A. S. Putra, O. M. Febriani, and B. Bachry, "Implementasi Genetic Fuzzy System Untuk Mengidentifikasi Hasil Curian Kendaraan Bermotor Di Polda Lampung," SIMADA (Jurnal Sist. Inf. dan Manaj. Basis Data), vol. 1, no. 1, pp. 21-30, 2018.

[27] A. S. Putra, H. Sukri, and K. Zuhri, "Sistem Monitoring Realtime Jaringan Irigasi Desa (JIDES) Dengan Konsep Jaringan Sensor Nirkabel," IJEIS (Indonesian J. Electron. Instrum. Syst., vol. 8, no. 2, pp. 221-232.

[28] D. P. Sari, O. M. Febriani, and A. S. Putra, "Perancangan Sistem Informasi SDM Berprestasi pada SD Global Surya," in Prosiding Seminar Nasional Darmajaya, 2018, vol. 1, no. 1, pp. 289-294. 